\title{
The Comparison Between Anti-Inflammatory Effects of Ethanol Extract from Kaempferia galanga L. and Diclofenac Sodium Induced by Carrageenan
}

\author{
$1^{\text {st }}$ Galih Samodra \\ Pharmacy Study Program, Faculty of Health Science \\ Harapan Bangsa University \\ Purwokerto, Indonesia \\ galihsamodra@uhb.ac.id
}

\author{
$2^{\text {nd }}$ Dina Febrina \\ Pharmacy Study Program, Faculty of Health Science \\ Harapan Bangsa University \\ Purwokerto, Indonesia \\ dinafebrina@uhb.ac.id
}

\begin{abstract}
Steroid and non-steroid anti-inflammatory drugs have many side effects so that many anti-inflammatory developments are made from natural ingredients, especially in plants. Plants that are scientifically proven to have antiinflammatory characteristic, one of which is from Zingiberaceae family. Kencur (Kaempferiae galangal L.) is a type of herb and medicinal plant that has been widely recognized by Indonesian people. Further research needs to be conducted to determine the comparison of the effectiveness of kencur extract with sodium diclofenac as an anti-inflammation. The parameter observed in this study was inhibition of edema on the rat's foot after induced by $0.1 \mathrm{~mL}$ of $1 \%$ carrageenan for 390 minutes. Edema volume was measured by using a plethysmometer. A total of 15 male rats weighing 200-250 gr were divided into 5 groups, namely the negative control group who were only given a PGA of $2 \%$, the positive control which given sodium diclofenac $20 \mathrm{mg} / \mathrm{Kg}$ of weight, and the extract group dose of kencur rhizomes respectively 45,90 and $180 \mathrm{mg} /$ kg. Edema volume measurement was performed every 30 minutes to 390 minutes. Edema volume data was used to calculate the percentage of edema inhibition, then the data were analyzed using one-way ANOVA and followed by LSD test to see the differences between groups. Ethanol extract of kencur with doses of 45 and $90 \mathrm{mg}$ / Kg of weight at the 5th and 6th hours showed significantly different anti-inflammatory activity compared to the positive controls where the $p$ value $<0.005$. This result shows that the ethanol extract of kencur can be used as an anti-inflammatory agent in male rats.
\end{abstract}

Keywords: Kaempferia galanga L., plethysmometer, diclofenac sodium

\section{INTRODUCTION}

Inflammation is a normal response to injury. When an injury occurs, substances such as histamine, bradykinin, prostaglandin, and serotonin are released. That process causes vasodilation and increased permeability of capillary walls. Pain receptors experience excitability, protein and fluid coming out of the capillaries (cells). Blood flow to the site of injury increases and phagocytic cells (leukocytes) migrate to the site of injury to damage substances that are considered dangerous. If the phagocytosis process is excessive, it will actually increase inflammation which is characterized by redness, swelling, heat, pain and loss of function [1].

Some studies suggest that chronic inflammation is closely related to an increase in cellular mutations that initiate cancer [2]. Inflammation that occurs continuously in blood vessels contributes directly to the formation of plaque in artery walls resulting in narrowing of blood vessels and causing high blood pressure, heart attacks, and strokes [3; 4]. Other diseases that involve chronic inflammatory processes in the body include arthritis, asthma, diabetes, allergies, anemia, Alzheimer's disease, fibrosis, fibromyalgia, systemic lupus, psoriasis, pancreatitis, and autoimmune diseases [5] so antiinflammatory drugs are needed.

Some anti-inflammatory drugs work on the mechanism of inhibiting prostaglandin synthesis which is known to act as a major mediator in inflammation. There are several classes of antiinflammatory drugs including steroid and nonsteroidal anti-inflammatory drugs. Antiinflammatory drugs of steroids are known to inhibit phospholipase A2 in the synthesis of arachidonic acid, so it has a potent antiinflammatory effect, but it is known that the use of these drugs in the long term will actually cause side effects such as hypertension, osteoporosis, and growth inhibition. Some literatures also mention that long-term use of steroids can increase the risk of cancer, heart disease and liver. It was also mentioned that the topical use of steroids in some people resulted side effects including dermatitis, diabetes mellitus and tissue atrophy [6].

Kencur (Kaempferia galanga L.) is a tropical plant that grows in various regions in Indonesia as a pet plant. This plant is widely used as a mixture of traditional medicine and as a spice in cooking so that many farmers are cultivating kencur as agricultural products that are traded. The root of kencur in the soil which also be traded called kencur rhizome [7]. 
Kencur rhizome has been widely known in the community either as a food seasoning or for medicine, including coughing, nausea, swelling, ulcers and fungal infection. Besides that, kencur rice herbal drink has some effects to increase endurance, eliminate colds and fatigue, be a mixture of massage oil together with coconut oil or alcohol to massage the sprained leg or tight muscle. The components contained in it include saponins, flavonoids, polyphenols and essential oils. This plant belongs to the monocotyledonous class, Zingiberales ordo, Zingiberaceae family and the Kaempferia genus [8].

In Hasanah's study [9], kencur rhizomes were obtained from Subang Regency. The results showed that the kencur rhizome has antiinflammatory activity, where the greater the dose given, the greater anti-inflammatory activity produced. The results of a significant percentage of inhibition were shown in treatments with a dose of $45 \mathrm{mg} / \mathrm{kg}$ of weight, the percentage of inhibition produced was $51.27 \%$. The antiinflammatory mechanism in kencur is believed to inhibit the release of serotonin and histamine to the site of inflammation and inhibit prostaglandin synthesis from arachidonic acid by inhibiting the action of cyclooxygenase $(\mathrm{COX})$. The compound that is assumed to provide antiinflammatory activity is flavonoids.

\section{METHODS}

\section{A. Preparation of extract}

Kencur rhizome is made to dry simplicia. The method used to make the extract was maceration using $70 \%$ ethanol as a solvent. Comparison between dry galangal rhizome powder with ethanol was 10:75. 2.5 $\mathrm{kg}$ of simplicia powder were macerated with $96 \%$ ethanol for 72 hours, then the filtrate was separated by filtration using a Buchner funnel. Then the filtrate was evaporated with a rotary evaporator with an optimum temperature of $40-50{ }^{\circ} \mathrm{C}$. The extraction process was repeated three times and the combined ethanol extract was evaporated to dryness at a temperature of $35^{\circ} \mathrm{C}$ above the water bath until a thick extract was obtained.

\section{B. Carrageenan $1 \%$}

A total of $0.9 \mathrm{~g}$ of $\mathrm{NaCl}$ was dissolved in distilled water until a final volume of $100 \mathrm{~mL}$ was obtained. A total of 0.05 grams of carrageenan dissolved in $0.9 \% \mathrm{NaCl}$ solution to obtain a final volume of $5 \mathrm{~mL}$. Carrageenan function was to induce edema in the rat's feet.

C. Making of $2 \%$ PGA Solution

PGA as a suspending agent was used to suspend sodium diclofenac and galangal rhizome ethanol extract. $500 \mathrm{mg}$ of PGA was mixed in a mortar with $35 \mathrm{~mL}$ of hot aquadest and diluted to obtain a final volume of $100 \mathrm{~mL}$ with distilled water.

\section{Diclofenac Sodium Dose}

Diclofenac sodium was used as a positive control of anti-inflammatory effects in rats, the dose given was $10 \mathrm{mg} / \mathrm{kg}$. $10 \mathrm{mg}$ of diclofenac sodium were suspended with 2\% PGA until a final volume of 25
$\mathrm{mL}$ was obtained. Diclofenac sodium functions as a positive control in testing anti-inflammatory activity.

E. Doses of Ethanol Extract of Kencur Rhizome

The doses of kencur extract given to animals are 45, 90, $180 \mathrm{mg} / \mathrm{Kg}$ of weight orally. The ethanol extract of kencur was suspended in 2\% PGA until a final volume of $25 \mathrm{~mL}$ was obtained.

F. Preparation of Animals

All Wistar strain-rats used to test antiinflammatory effects were acclimatized first, placed in an animal room under normal conditions of $24 \pm 1 \mathrm{oC}$, 12-hours of dark cycle and $55 \pm 5 \%$ humidity for a week and before the experiment the rats were fasted for 18 hours while still giving water intake. The animals that will be used in the experiment are healthy rats, which did not experience a change in body weight> $10 \%$ during acclimatization and showed normal behavior.

G. Anti-inflammatory Activity Test

Twenty-five rats were divided into five groups randomly. Before testing, rats were fasted for 18 hours while still given drinking water. Rats were marked on their left foot, then foot volume was measured before treatment using a plethysmometer. Each animal was given a test preparation orally according to the group. After 1 hour, each rat was induced $0.1 \mathrm{~mL} \lambda$ carrageenan $1 \%$ sub-plantar. Edema volume measurement was performed every 30 minutes for 390 minutes after induction of carrageenan.

\section{H. Data Analysis}

Data were tested for normal distribution and homogeneity of variants ( $p>0.05$ ), then data were analyzed using One-Way ANOVA and LSD follow-up tests with $95 \%$ confidence level.

\section{RESULTS AND DISCUSSION}

\section{Anti-inflammatory Activity Testing of Kencur Rhizome Extract in Vivo in Female Rats}

Induction of carrageenan can increase edema volume in the rats which can be seen in edema volume before and after administration of carrageenan. Edema in carrageenaninduced hind limbs is one of the standard models of acute inflammatory trials [10] that are responsive to cyclooxygenase (COX) inhibitors and are often used for screening the effects of non-steroidal anti-inflammatory drugs (NSAIDs) [11]. This method is an acute inflammatory testing method that is widely used, and has various advantages including easy procedure, does not cause tissue damage, is irreversible within 24 hours, is not antigenic and does not cause systemic effects $[12 ; 13 ; 14]$. Figure 1 shows the rats' foot edema volume measured every 30 minutes for 6.5 hours after carrageenan induction, then the mean of edema the following chart: 


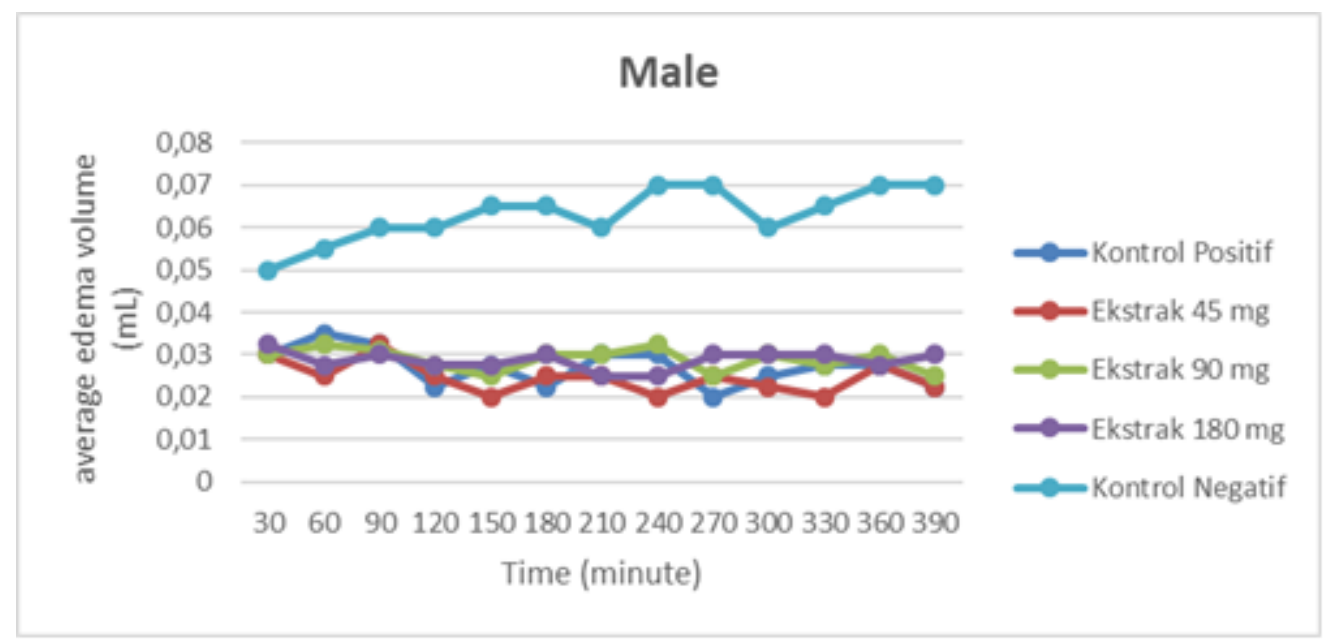

Figure 1. Graph of mean edema volume to the time in anti-inflammatory test with a dose of $45 \mathrm{mg} / \mathrm{Kg}$ of weight, $90 \mathrm{mg} / \mathrm{Kg}$ of weight and $180 \mathrm{mg} / \mathrm{Kg}$ of weight, positive control of diclofenac $\mathrm{Na}$ and negative control of $2 \%$ PGA.

Figure 1. shows the edema volume in the 30th to 390th minutes edema volume at the positive treatment and control group was smaller than the negative control group. In the negative control group, injection of carrageenan produced continuous increase of edema from the 30th minute to the 390th minute. Carrageenan is able to induce cell injury so that injured cells release various mediators that initiate the inflammation process. Edema caused by carrageenan depends on the role of kinin, polymorphonuclear leukocytes, and inflammatory mediators released such as PGE1, PGE2, and PGA [15]. According to Tumbach [16], the administration of sub plantar carrageenan will increase COX-2 levels. Based on Figure 1, it can then be calculated the mean percentage of edema in the soles of rats after induction of carrageenan in each treatment, the test results can be seen in Figure 2.

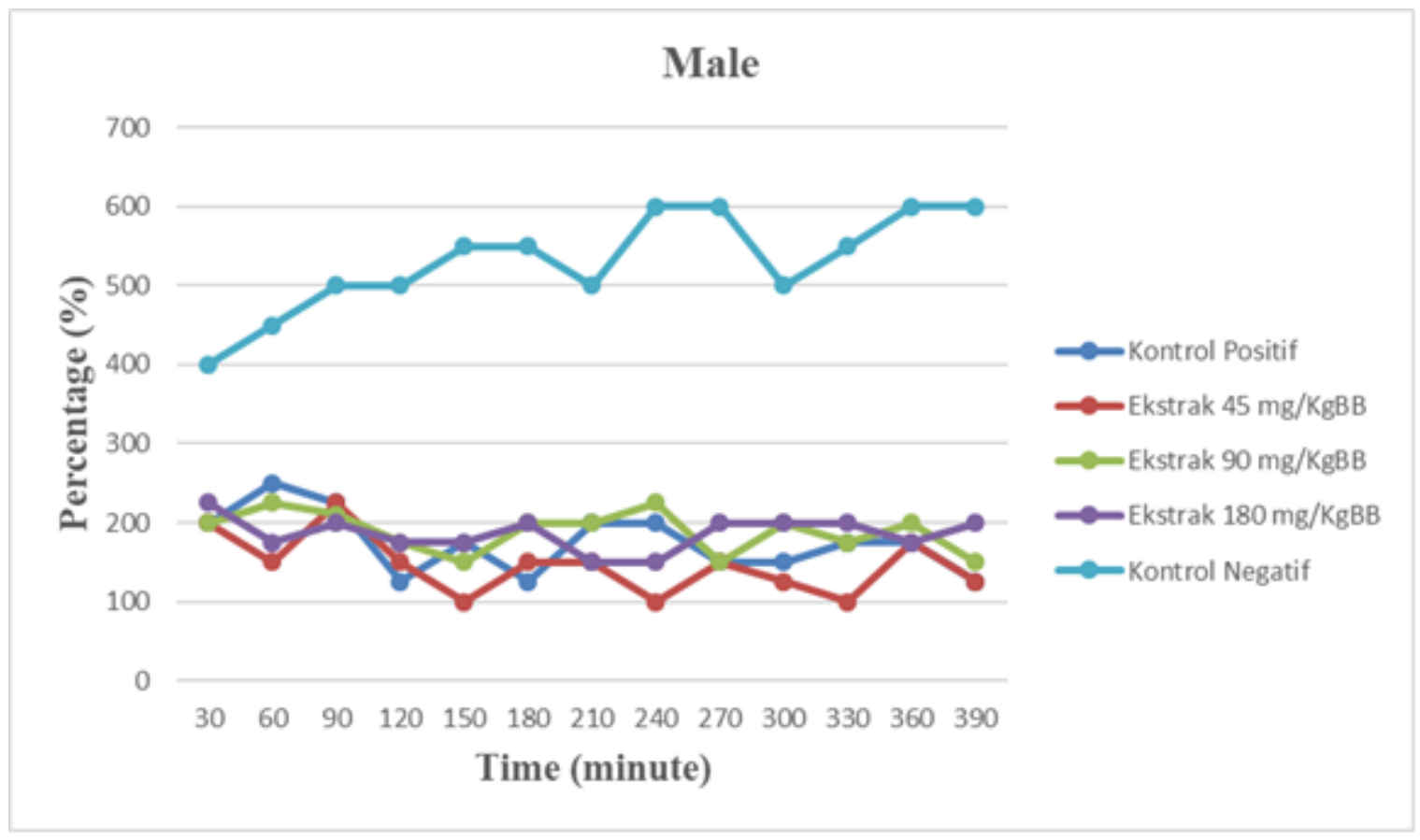

Figure 2. Graph of relationship between mean percentage of edema and the time

The percentage of inflammation caused by carrageenan injection in the treatment group was smaller than in the placebo group as well as in the positive control group (sodium diclofenac). The percentage of maximal inflammation in the treatment group and the positive control was reached in the 60 th minutes. The ability of a material to be able to reduce inflammation in lab animal's feet due to injection of carrageenan is expressed as a percentage of inhibition. The percentage of inhibition for each group can be seen in figure 3 . 


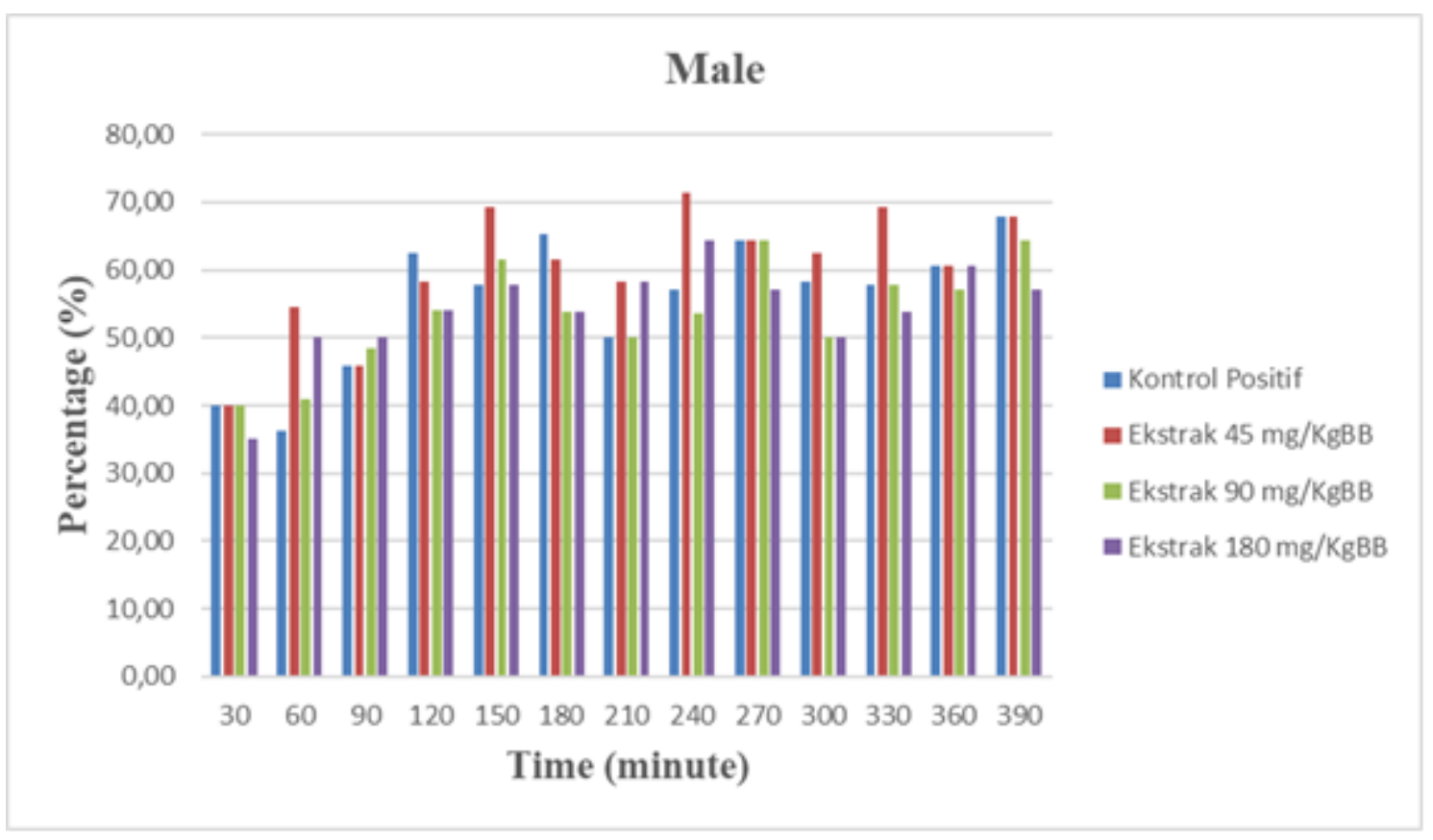

Figure 3. Graph of the relationship of the mean percentage of edema inhibition to the time.

Based on the results of the study it was seen that the three dose variations in the test group showed their ability to inhibit edema formation. The percentage of edema inhibition in the group with a dose at $45 \mathrm{mg} / \mathrm{Kg}$ of weight over time has increased and is the most optimal. The mean value of the percentage of edema inhibition at doses of 45, 90, and 180 $\mathrm{mg} / \mathrm{Kg}$ of weight are respectively $(60.27 \% ; 53.51 \% ; 54 \%)$ starting from the 30th minute to the 390th minute. This result shows that administration of the drug for 2.5 hours by oral has shown the action of kencur rhizome extract in inhibiting inflammation around the feet of rats. The inhibitory characteristic of the test compound at a dose of $45 \mathrm{mg} / \mathrm{kg}$ body weight as an anti-inflammatory result shows greater results compared to positive control (Sodium diclofenac 20 $\mathrm{mg} / \mathrm{kg}$ body weight), test dose 2 (90 $\mathrm{mg} / \mathrm{kg}$ body weight) and test dose 3 (180 mg / kg body weight) in the 240th minute.

The results of calculating the percentage of edema inhibition were then input into the ANOVA statistical test using the SPSS version 25 application to analyze and see whether the data met the ANOVA requirements, namely normality and homogeneity test data. The normality test was performed using Kolmogrov-Smirnov method and homogeneity tests used the Levene method to see the distribution of percent data of rat's foot edema inhibition at the $1_{\text {st }}$ to 6 th hours, where the results showed that at the 5 th and 6 th hours it had significant differences with a positive control group with the results of Sig. respectively were 0.040 and 0.045. Next, it was proceeded with LSD test (Least Significant Difference) using LSD method to see the differences between treatment groups. The result showed that there were significant differences between the dose groups of 45 and $90 \mathrm{mg} / \mathrm{Kg}$ of weight and the positive control group. This proved that doses of 45 and $90 \mathrm{mg} / \mathrm{Kg}$ of weight of ethanol extract of kencur rhizome have anti-inflammatory activity.

From the results of phytochemical screening, it was known that ethanol extract of kencur rhizomes included flavonoid and tannin chemical compounds. The compounds that may be responsible for anti-inflammation are flavonoids and tannins. Flavonoids have an important role in maintaining permeability and increasing capillary resistance. Flavonoids inhibit the process of inflammation in two ways, namely by reducing capillary permeability and inhibiting arachidonic acid metabolism and secretion of lysosomal enzymes from neutrophil cells and endothelial cells [17]. Flavonoids mainly work on microvascular endothelium to reduce the occurrence of hypermeability and edema [18]. Flavonoids are also known to have the ability to protect cell structures, as antioxidants, and anti-inflammatory [19]. Besides flavonoids, the content of polyphenols is also known to inhibit lipoxygenase, which is closely related to the mechanism of inflammation [20]. Tannins also have antiinflammatory activity, but the mechanism cannot be explained [21].

\section{CONCLUSIONS}

Ethanol extract of kencur rhizome in male rats with doses of 45 and $90 \mathrm{mg} / \mathrm{Kg}$ of weight has anti-inflammatory activity but it is still lower than anti-inflammatory activity of positive control sodium diclofenac dose of $20 \mathrm{mg} / \mathrm{Kg}$ $\mathrm{BW}$ at the 5th and 6th hours. Whereas the administration of kencur rhizome ethanol extract using female rats at the 5th hour at doses 45, 90 and $180 \mathrm{mg} / \mathrm{Kg}$ BW showed significant differences with the positive control group with Sig. are $0.002 ; 0.004 ; 0.002$, respectively. From the three doses of kencur rhizome extract it is known that the greatest anti-inflammatory effect is found at a dose of 45 
$\mathrm{mg} / \mathrm{Kg}$ WB with the smallest mean difference of edema foot volume. This study shows that the ethanol extract of kencur rhizome for male has anti-inflammatory activity at all dosage levels.

\section{ACKNOWLEDGMENT}

The researchers convey the acknowledgement to the Pendidikan Dwi Puspita Foundation through the Harapan Bangsa University Research Institute which has funded this research

\section{REFERENCES}

[1] Priyanto, 2008, Farmakoterapi Dasar untuk Mahasiswa Keperawatan dan Farmasi, Leskonfi, Jakarta.

[2] Albini, A. \& Sporn., M.B., 2007, The Tumour Microenvironment as a Target for Chemoprevention, Nature Reviews Cancer, 7, 139-147.

[3] Libby, P. \& Okamoto, Y., 2010, Inflammation in Artherosclerosis: Transition from Theory to Practice, Circulation Journal, 74(2), 213-220.

[4] Patel, S. \& Celermajer, D.S., 2008, Artherosclerosis: Underlying Inflammatory Mechanisms and Clinical Implications, Int. J. Biochem. Cell Biol., 40(4): 576580. [5] Borne, R., Revi, M., \& Wilson, N., 2008, Nonsteroidal Anti-Inflammatory Drugs dalam Lemke, T.L., Williams, D.A., Roche, V.F., \& Jito, S.W., (Eds.), Foye's principles of medicinal chemistry 6th Ed., 2-5, William \& Wilkins, Philadelphia.

[6] Judarwanto, W. \& Dewi, N., 2012, Kortikosteroid Topikal, Jenis Penggolongan dan Efek Sampingnya, http://allergyclinic.wordpress.com/2012/06/04/kortikost eroid-topikal-jenispenggolongan-dan-efek sampingnya/, 25 April 2019.

[7] Barus, Rosbina, 2009, Amidasi Etil pMetoksi Sinamat yang Diisolasi dari Kencur (Kaempferia galanga Linn.), Tesis, Kimia Pasca Sarjana, USU, Medan. [8] Winarto, W. P., 2007, Tanaman Obat Indonesia Untuk Pengobatan Herbal, 152153, Jakarta, Karyasari Herba Media.

[9] Hasanah A. N., Fikri N., Ellin F., dan Ade Z. Analisis Kandungan Minyak Atsiri dan Uji Aktivitas Antiinflamsi Ekstrak Rimpang Kencur (Kaempferiae galanga L.). Jurnal Matematika \& Sains. 2011;16(3):147-152.

[10] Chakraborty, A. R. K. B., Devi, S., Rita, K.H., Sharatachandra, T.H., \& Sing, I. 2004. Preliminery Studies on Antiinflamatory and Analgesic Activities of Spilanthes acmella in Experimental Animal Models. Indian Journal Pharmacology, Vol 36 (3): 148-150.

[11] Logeswari, P., Dineshkumar, V., Kumar., S. M. P., \& Usha, P. T. A., 2013. In-vivo Antiinflamatory Effect of Aqueous and Ethanolic Extract of Sida rhombifolia L. Root. IJPSR, Vol 4(1):326-321.

[12] Fitriyani, Atik., Lina Winarti., Siti Muslichah dan Nuri. 2011. Uji Antiinflamasi Ekstrak Metanol Daun Sirih Merah (Piper crocatum Ruiz \& Pav.) Pada Tikus Putih. Majalah Obat Tradisional, 16(1), 34 - 42, 2011.
[13] Hidayanti, Nur Annis., Shanti Listyawati., Ahmad Dwi Setyawan. 2008. Kandungan Kimia dan Uji Antiinflamasi Ekstrak Etanol Lantana camara L. pada Tikus Putih (Rattus norvegicus L.) Jantan. FMIPA UNS Surakarta. Bioteknologi 5 (1): 10-17.

[14] Nile, Shivraj Hariram and Se Won Park. 2013. Optimized Methods for In Vitro and In Vivo AntiInflammatory Assays and Its Applications in Herbal and Synthetic Drug Analysis. Mini-Reviews in Medicinal Chemistry, Vol. 13, PP. 95-100.

[15] Amanlou, M.F., Dadkhah, A., Salehnia, H., Farsam, \& Dehpour, A.R., 2005. An antiinflammatory and Anti nociceptive Effects of Hydroalkoholic Extract of Satureja khuzistanica Jamzad Extract. Journal Pharmacology and Pharmaceutical Science,Vol 8(1): 102-106.

[16] Tumbach, M. E., Spraggins, D. S., \& Randich. 2002. Spinal Administration of Prostaglandin E2 or Prostaglandin F2 $\alpha$ Primarily Produces Mechanical Hyperal That is Mediated by Nociceptive Specific Spinal Dorsal Horn Neuron. Pain. 97: 33-45.

[17] Kurniawati. 2005. Uji Aktivitas Antiinflamasi Ekstrak Metanol Graptophillum griff pada Tikus Putih. Majalah Kedokteran Gigi Edisi Khusus Temu Ilmiah Nasional IV, 11-13 Agustus 2005, 167-170.

[18] Sabir. 2010. Pemanfaatan flavonoid di Bidang Kedokteran Gigi. Majalah kedokteran Gigi Edisi Khusus Temu Ilmiah Nasional III. 6-9 Agustus 2003: 81-83.

[19] Subroto, M. A. \& Saputro, H. 2006. Gempur Penyakit dengan Sarang Semut. Penebar Swadaya. Jakarta. Hal. 27.

[20] Robinson T. 1991. Kandungan Organik Tumbuhan Tinggi. Terjemahan oleh Kosasih Padmawinata. Bandung; Institut Teknologi Bandung; 1995.hal. 192.

[21] Khanbabae, K., \& Ree,T. V., 2001, Tannins: Classification and Definition. Nat Prod Rep, 18:641-49. 